\title{
«NOvuMEDICAL» DEVICES ARE THE VECTOR OF REALIZATION OF P4 MEDICINE COURSE
}

\author{
Irina Shuvalova \\ Department of health and rehabilitation \\ V. I. Vernadsky Crimean Federal University, Academy of Medical and Technical Sciences
}

\begin{abstract}
The issues of modern personified preventive medicine, the development of modern methods, courses, technologies of healthy active longevity are in the focus of attention and these issues are relevant. The purpose of the article is to study the influence on prevention of diseases, improving the quality of life by massage and thermal device «NovuMedical» intended for home use.

In the research the analysis of results of the equipment use in 140 patients aged from 61 to 78 years is conducted by the method of comparison and grouping. A significant improvement in the quality of life, stabilization of the psycho-emotional state and blood pressure is noted among $93.5 \%$ of patients. Reduction of pain syndrome is noted among $85 \%$ of patients, reduction in serum cholesterol is noted among $30 \%$, glucose normalization is noted among $25 \%$ of patients, and $46 \%$ has a tendency to reduce it. A tendency to normalize blood coagulation function is noted among $40 \%$ of patients, that makes prevention and correction of diseases legitimate and necessary, timely with the help of «NovuMedical» devices at home. «NovuMedical» devices allows both to improve well-being, normalize homeostasis, and to form in patients a system of knowledge and skills to improve the quality of life, and include them in active actions for health self-improvement, mental and physical self-improvement. This participatory approach leads to a fundamentally new paradigm of caring and managing health, when not only the social institutions of the state, but also patients themselves are direct and active participants in the process of preserving and strengthening their own health.
\end{abstract}

Keywords: device for home use, quality of life, preventive medicine, health promotion, participatory medicine.

\section{Introduction}

It is well-known that it is easier to prevent any disease than to heal it. The prophylaxis of diseases, age pathology, increase of the active longevity and life quality of humans are ones of most important problems of health protection and is especially urgent in the context of the coming pension reform $[1,2]$. Preventive medicine plays a leading role in saving health of a modern human, just that is why the great attention is paid to it, innovation technologies are improved and developed [3,4], and also molecular physiological processes of ageing are studied for correcting them that inevitably results in diseases prophylaxis and ageing speed decrease [5]. A risk of any pathology is conditioned by not only genetic but also epigenetic factors. Main epigenetic factors include - the food quality, life style, ecological environment [6, 7]. All these factors influence appearance and progress of many acquired diseases, which genetic predisposition is inherent to each human. Modern preventive medicine proposes a complex of arrangements, oriented on decreasing a risk of appearance and development of acquired diseases and their consequences. It is in first turn, an individual or personalized approach that distinguishes preventive medicine from other ones $[8,9]$. It is well-known that a sustainable remission is possible only at understanding of the importance of healthy life style and personal responsibility for own health by each human.

The most famous American inventor of XX century Tomas Alva Edison, who registered 1093 patents in the USA and 3000 ones in other world countries, said words which meaning is undoubted for all medical scientists even now, after a century: A future doctor will not give drugs to a patient, he/she will try to interest a patient in observing own organism condition, diet, and prevention of diseases".

Main strategic directions of developing the system of health protection in the RF for the period till 2035, included in roadmap are: "Health and longevity", "Preventive medicine", "Biomedicine" and other [10]. And this is just not occasionally. According to most Russian and foreign experts, main trends of developing national strategies of health protection for the nearest 20 years will be: personalization of medicine, mass approach to preventive medicine, mass transfer to it, 
course for active longevity, stable growth of popularity of naturopathic and preventive methods of prophylaxis and healing of diseases [11, 12].

In 2002 in Paris there was created the European association of anti-age medicine (ESAAM), named today the "European association of preventive, regenerating and anti-age medicine". It created a new interdisciplinary direction in medical science and practice - Medicine - "4P"; predictive, preventive and personalized, participative - partner with patients that, from our point of view, may be a base for the future development of prophylactic medicine.

The decrease of the level of morbidity, tenderness, invalidism and also saving, strengthening and restoration of health, increase of life duration can be attained only using innovative preventive methods of diagnostics, healing and prophylaxis. The early diagnostics of diseases is extremely important, but without means influencing correction of found pathological disorders it is incorrect to say about predictive medicine $[13,14]$. The use of preformed physical factors for correcting pathological disorders in prophylactic and restorative healing usually stimulates sanogenetic mechanisms of the organism and organ level, improving the tissue and cellular methods that inevitably results in the reverse development of a pathological process and its stabilization [15].

Direction of healing in home conditions, which bright representative is a company «NovuMedical», results in a principally new paradigm of caring about health, when not only all social institutes of a state, but country dwellers themselves, first of all the most conscious and educated part of the population, become direct active participants of the process of saving health.

\section{Aim of the article}

To study the influence of «NovuMedical» equipment on the prophylaxis of diseases, patients' life quality increase.

\section{Research materials and methods}

The research included studying patients' healing processes in 50 free demonstration centers (FDC) «NovuMedical» of Russia, Ukraine, Kazakhstan. FDC «NovuMedical» provides studying and demonstration of possibilities of the massage-thermal equipment for removing fatigue and stress, full-value rest, improving mood and state of health, everyday care for health of eyes, legs and spine, primary and secondary prophylaxis of diseases. Having convinced him/herself in the personal efficiency of the equipment, a patient buys a device for further using it in home conditions. FDC specialists realize the dynamic observation over patients in the healing process under home conditions. For the period of 2014-2017 142000 patients were treated in centers, more than 5000 patients a day visit centers, their average age is $65 \pm 3.6$ years.

For correcting acquired diseases and their prophylaxis, there were used «TopRelax», «NovuHeat», «NovuEye» «BodyHealth» devices.

«TopRelax» (Corea) - it is a vibro-massage device that makes diverse rhythmic, vibration percussions with a possibility of including infrared heat to $770 \mathrm{~nm}$. Magnets, inserted in the device, create a constant magnetic field in the working process - $72 \mathrm{mT}$, and tourmalin inserts enrich impact zones by negative air ions -1000 ions for $\mathrm{cm}^{3} \pm 200$. Obtained energy radiates heat, the local heating is realized. Infrared energy can penetrate tissues of the organism by waves, also heating them. At the expanse of vibratory massage there is realized the purposeful system of transmitting mechanical vibrations on the human body for affecting its different organs and systems at the expanse of irritating receptors of the skin, muscles and tendons surfaces. Such impacts result in creating electric moving systems, transformation of energy of acting factors in energy of cells of the organism, widening vessels and accelerating the movement of blood flows and other liquids inside the organism.

«NovuEye» (Corea) - a massage device for eyes, it realizes acupressure of points of eyes, vibratory massage, infrared heat to $770 \mathrm{~nm}$, constant magnetic field $-85 \mathrm{mT}$, ionization -1000 ions for $\mathrm{cm}^{3} \pm 200$. 
«NovuHeat» (Corea) - a thermal carpet, enriched with magnets and tourmaline, for heating the body to 70 degrees, impact by infrared heat to $770 \mathrm{~nm}$, ionization of impact zones - 1000 ions for $\mathrm{cm}^{3} \pm 200$, constant magnetic field $-30 \mathrm{mT}$.

«BodyHealth» (Corea) - a miostumulator with a changing configuration of electric impulses, allowing to activate the blood circulation effectively, completely painlessly and safely. The impulse duration $-0.5-300 \mathrm{~m} / \mathrm{s}$. Impulse frequency - 10-150 Hz. Form of impulses - neuron-like. A device is designed for the restoring healing of vessels of low extremities, active factors are miostimulation, stimulation of reflectory points of feet and infrared heat.

Thus, active preformed physical factors, used in these devices, are: constant magnetic field, infrared heat, ionization, mineral therapy, miostimulation, apparatus massage techniques. They all are studied well, and their use for treating and preventing purposes is scientifically grounded $[16,17]$. The function mechanism of physical factors is based on their energy transformation in one of biological processes, as a result therapeutic effects develop - anti-inflammatory, analgesic, tropic and so on $[11,18]$.

A series of works on studying «NovuMedical» equipment demonstrates that these devices are rather effective in primary and secondary prophylaxis of diseases of the vertebral-neurologic profile [19, 20], eyes, peripheral vessels of legs [21], normalize homeostasis, activate sanogenetic mechanisms of the organism, have immune-modeling, stress-limiting, geroprotective effects [22].

The study included 140 patients. The analysis of the effectiveness of using «NovuMedical» devices for for prophylactic of diseases and healing patients in home conditions was realized by the method of grouping and comparison. Examined persons were 99 women and 41 men, 61-78 years old. All them underwent out-patient and stationary examination and treatment and had a fixed disease. Among the examined patients, $100 \%$ had a certain "bouquet" of so-called age diseases. Thus, $85 \%$ had diseases of the cardio-vascular system, $70 \%$-diseases of the locomotor system, $50 \%$ - diseases of peripheral vessels, $55 \%$ - diseases of internal organs, $80 \%$ - of eyes, $30 \%$ - of respiratory organs. $89 \%$ had lipid metabolism disorders, $56 \%$ - carbohydrate metabolism, $72 \%$ - disorders of the coagulating system. As far as patients had different combinations of diseases, each one had own "bouquet" of diseases, we separated them conventionally in groups, depending on the level of deviations of biochemical indices of blood from the norm. Thus, glucose level less $7 \mathrm{mmol} / \mathrm{l}$ was fixed in 20 persons, from 7 to $10 \mathrm{mmol} / \mathrm{l}$ - in 35 persons, more than $10 \mathrm{mmol} / 1$ - in 22 persons. Patients with lipid metabolism disorders were grouped analogously, because the cholesterol level in blood serum less $7 \mathrm{mmol} / \mathrm{l}$ was revealed in 38 persons, higher $7 \mathrm{mmol} / \mathrm{l}$ - in 87 persons. The prothrombin index less than $100 \%$ was revealed in 40 persons, more $100 \%$ - in 61 persons.

Patients underwent the examination of biochemical blood parameters in 'Synevo" laboratory, certified by the international standard of managing a quality 9001:2000. The statistical processing of research results was made using STATISTICA v.6.0 professional course.

\section{Research results}

According to the data of the interrogation, questionnaire, interviewing, $93.5 \%$ of patients noted the essential increase of the general health state, life quality improvement. Patients noted the sleep improvement (92\%), mood improvement (98\%), interest and pleasure of life (87\%), state of psycho-emotional comfort (96\%), stress-resistance increase (86\%), everyday activity (94\%) Fig. 1.

It was established, that the systematic use of the equipment results in $85 \%$ of patients in decreasing the pain syndrome. According to Oswestry's pain scale, the index of pain expressiveness decreased from $4.3 \pm 1.25$ before starting healing to $1.4 \pm 1.45$ points $(\mathrm{p}<0.05)$. In $20 \%$ there was observed the decrease of the arterial pressure to normal values, thus SAP decreased from $158.7 \pm 2.5$ to $125 \pm 7.2 \mathrm{mmHg}$. ( $\mathrm{p}<0.05)$. DAP from $97.3 \pm 3.2$ to $85 \pm 0.5 \mathrm{mmHg}$, respectively $(\mathrm{p}<0.05) .43 \%$ of patients demonstrated the dynamics to the arterial normalization, thus at initial SAP $175.3 \pm 3.5$, it decreased to $156.6 \pm 2.5$ ( $\mathrm{p}<0.05$ ), and DAP from $109.8 \pm 3.2$ to $96.2 \pm 0.5 \mathrm{mmHg}$, respectively $(\mathrm{p}<0.05)$, that resulted in correcting a dose of taken hypotensive preparations. The dynamics of biochemical parameters in blood of the examined patients in the healing process in home conditions using «NovuMedical» equipment is presented in Table $\mathbf{1}$. 


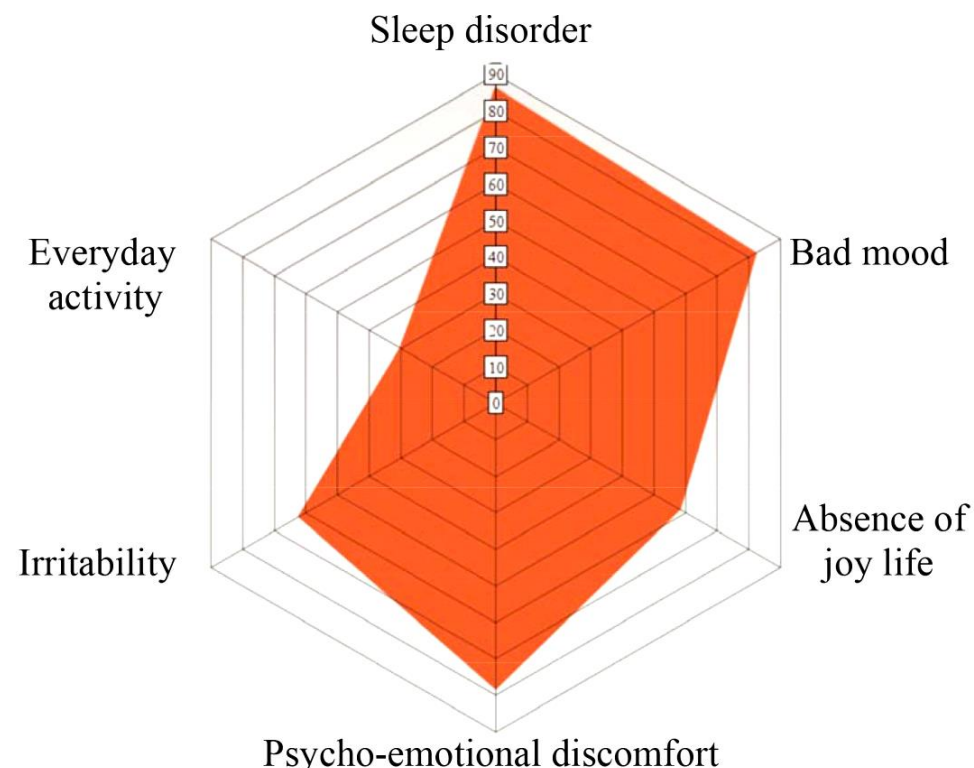

$a$

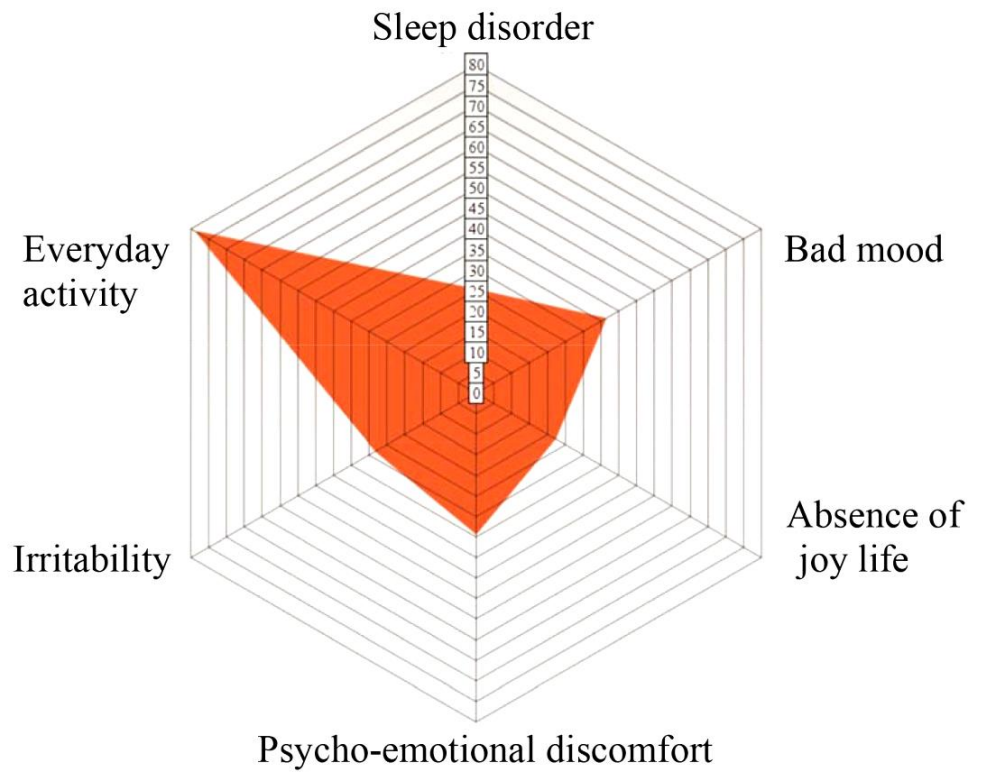

$b$

Fig. 1. Dynamics of subjective data: $a$ - before treatment; $b$ - after 3 months

In $30 \%$ of patients there was revealed the decrease of cholesterol content in blood serum, thus it decreased from $6.6 \pm 0.2$ to $5.8 \pm 0.1 \mathrm{mmol} / 1(\mathrm{p}<0.05)$, and triglycerides of blood in these patients decreased from $1.750 \pm 0.072$ to $1.556 \pm 0.069 \mathrm{mmol} / \mathrm{l}(\mathrm{p}<0.05)$. In $25 \%$ of patients there was observed normalization of the glucose level in blood from $6.3 \pm 0.4 \mathrm{mmol} / 1$ to $5.5 \pm 0.2 \mathrm{mmol} / 1(\mathrm{p}<0.05)$, and in $46 \%$ - there was fixed the positive dynamics to its decrease, thus at the initial glucose level in blood $9.4 \pm 0.2 \mathrm{mmol} / \mathrm{l}$ it decreased to $7.6 \pm 0.4 \mathrm{mmol} / 1(\mathrm{p}<0.05)$. In $40 \%$ of patients there was revealed the positive dynamics to normalizing the blood coagulating system, thus the prothrombin index $(\%)$ changed from $98.3 \pm 0.6$ to $90.2 \pm 0.5(p<0.05)$. The decrease of indices is not statistically reliable in patients with the high glucose blood level. Probably for reaching reliable results in this group of patients, the longer period of healing is needed (Fig. 2). 
Table 1

The dynamics of biochemical parameters in blood of the examined patients in the healing process in home conditions using «NovuMedical» equipment $n=140$

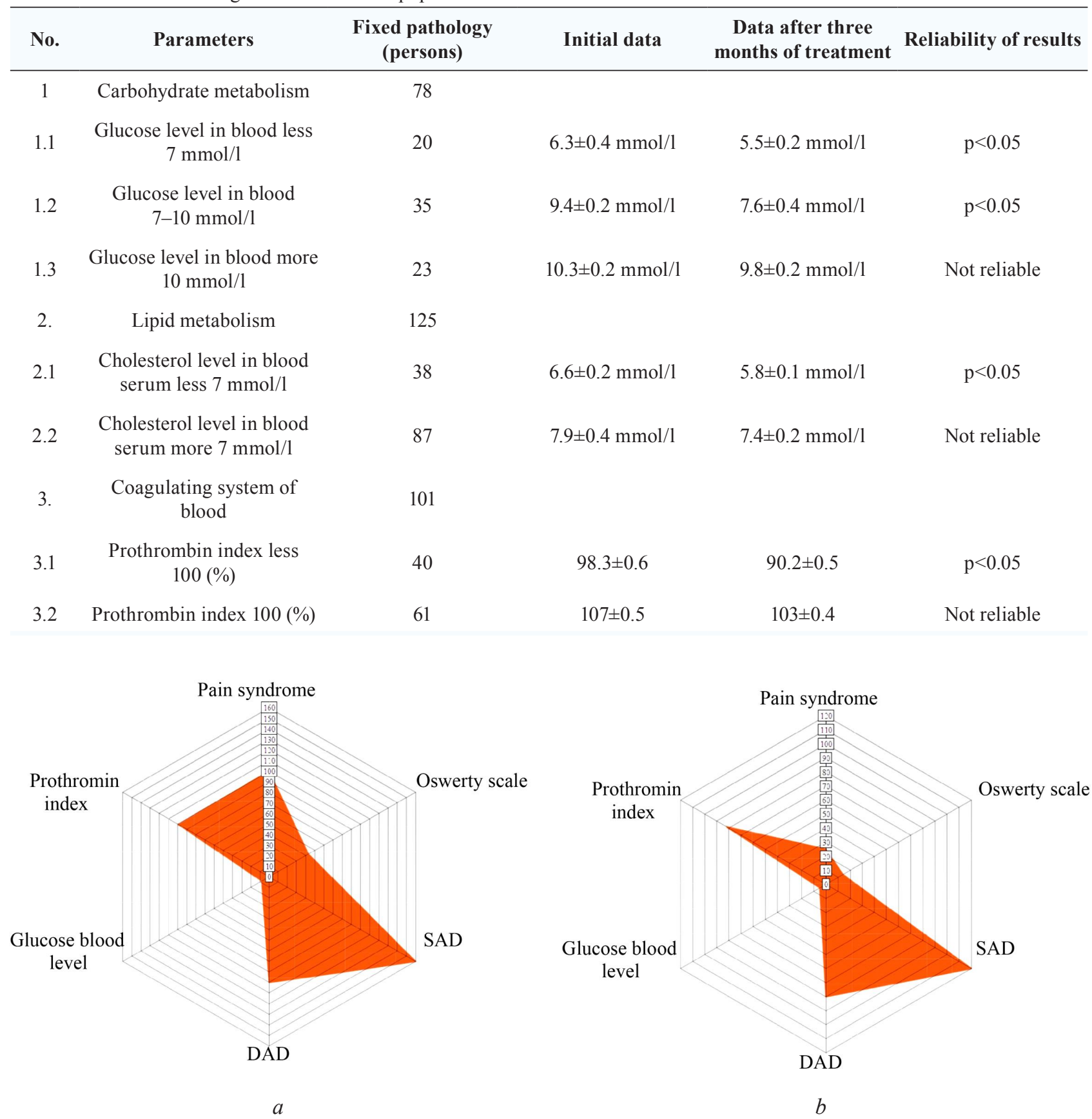

Fig. 2. Dynamics of objective data: $a$ - before treatment; $b$-after 3 months

The use of «NovuMedical» equipment causes the general adaptive transformation of the organism, including a psychic status, thus the anxiety degree by Spielberger, high in all patients before healing, both reactive and personal had a tendency to decrease. After using the equipment, the mean degree of anxiety stayed in $18 \%$ of patients, but indices were reliably lower than initial values $(<0.05)$.

\section{Discussion}

Physiotherapeutic and preformed healing methods are widely used in the treatment, prophylaxis and rehabilitation of patients with different diseases of the cardio-vascular, lo- 
comotor, nervous, respiratory and other systems, that is scientifically grounded [15, 17]. The studies demonstrate that physiotherapeutic methods are widely used at stationary and out-patient treatment stages. For preventing exacerbation of diseases, patients at remission may underwent the prophylactic treatment also in sanatoria institutions, where leading healing factors are climatic and physiotherapeutic ones that are very effective methods at preventing diseases $[14,18]$. But they are available for patients only one, in the best case, two times a year, the rest of the time patients usually stay face to face with their disease. But it is necessary to make prophylaxis and restoration of injured organs continuously $[6,12]$. Practical health protection cannot deal with these questions continuously because of a series of causes, and patient, having undergone a treatment in a hospital or finished a course one in a clinic, after eliminating acute manifestations of a disease and having returned home, needs continuation of healing for restoring disordered functions of the organism. In the study we demonstrated that at this contradiction, when a patient needs restorative treatment, but health protecting institutions are not able to deal with restoration of disordered functions of the organism at remission, the treatment in home conditions may be recommended by offering a patient to use individually chosen devices for home. Stable remission is possible only at understanding a necessity of healthy life style, personal responsibility for own health and everyday care for the organism, changed by a disease by each person.

The positive dynamics in the patients' state as a result of using a constant magnetic field, infrared heat, ionization, mineratotherapy, miostimulation, apparatus massage technique corresponds to data, presented in scientific works about this question $[11,16]$. The novelty of our study is the use of preformed factors in home conditions for everyday care for the injured spine, joints, muscles, eyes, feet, hands, vessels of low extremities.

Patients, who used preformed factors for prophylaxis in home conditions, demonstrated the increase of life quality, stabilization of psychoemotional state, arterial pressure. The everyday use of devices in home conditions results in normalization of hemodynamics, lipid, carbohydrate metabolism, blood coagulation system that confirms prophylaxis of diseases and their correction using home devices and makes it necessary.

During the study it was established, that the use of devices results in decreasing a pain syndrome, and just pain syndrome is an important esodic link that testifies to the incorrect or inaccurate attitude to the own body. That is why stopping a pain syndrome by pharmacological means in most cases doesn't favor patient's rehabilitation, but often decelerates or inhibits mechanisms of sanogenesis. Adequate parameters of physical factors, used in devices, stimulate the development of a cascade of reactions of sanogenesis in the patient's organism that allows to improve the health state and to normalize homeostasis, and everyday use of devices includes a patient in active steps for self-healing, physical and psychic self-improvement.

Scientific studies of preventive medicine more and more often talk about a necessity of the personified approach and correction of disease syndromes [8]. Healing of patients in home conditions by individually chosen preformed physical factors is a component of personified, preventing and participating medicine.

\section{Conclusions}

1. The obtained results testified to the effectiveness and prospects of using home devices for preventing diseases, because their use results in normalization of homeostasis, expressed in the positive dynamics of carbohydrate, lipid metabolism and improvement of blood rheology.

2. The use of home devices results in stabilizing the psychoemotional state, normalization of sleep and arterial pressure, improvement of patients' life quality.

3 . The use of the equipment in home conditions is a prospective direction that opens possibilities of improving healing results, not realized yet. It allows to include each patient in active steps for self-healing.

4. The use of «NovuMedical» home devices in everyday life and healing patients by them is a vector of realizing the course Medicine - "4P" in practice. 


\section{References}

[1] Moskalev, A. A. (2016). 120 let - eto tol'ko nachalo. Kak pobedit' starenie? Moscow: EKSMO, 265

[2] Trofimova, S. V. (2016). Vsya pravda o dolgoletii. Saint Petersburg: Traktat, 56.

[3] Gems, D. (2014). What is an anti-aging treatment? Experimental Gerontology, 58, 14-18. doi: http://doi.org/10.1016/j.exger.2014.07.003

[4] Trofimova, S. V., Trofimov, A. V. (2017). Innovatsionnye tekhnologii preventivnoy meditsiny. Vestnik vosstanovitel'noy meditsiny, 1, 37-40.

[5] Anisimov, V. N. (2008). Molekulyarnye fiziologicheskie mekhanizmy stareniya. Saint Petersburg: Nauka, 481.

[6] Trukhanov, A. I. (2012). Antiage medicine: nauka ostavat'sya molodym. Moscow: ASVOMED, 695.

[7] Vanyshin, B. F., Khavinson, V. Kh.; Doerfler, W., Bohm, P. (Eds.) (2016). Short Biologically Active Peptides as Epigenetic Modulators of Gene Activity. Epigenetics - A Different Way of Looking at Genetics. Springer International Publishing Switzerland, 69-90.

[8] Dontsov, V. I., Krut'ko, V. N. (2017). Personalizirovannaya korrektsiya sindromov stareniya kak novoe napravlenie preventivnoy meditsiny. Vestnik vosstanovitel'noy meditsiny, 1, 30-36.

[9] Il'nitskiy, A., Trofimova, S. V., Belov, D., Gazitaeva, Z., Biryukova, I., Zhaboeva, S. (2015). Preventivnaya geriatriya, kak novoe napravlenie v klinicheskoy praktike. Vrach, 6, 29-31.

[10] Trukhanov, A. I., Chudakov, S. Yu. (2017). Rol' preventivnoy meditsiny v sotsial'noy politike gosudarstva. Vestnik vosstanovitel'noy meditsiny, 1 (77), 8-17.

[11] Bykov, A. T., Chernyshov, A. V., Drozdova, V. M. (2017). Fizicheskie metody profilaktiki, lecheniya i reabilitatsii: proshloe, nastoyashhee i budushhee. Vestnik fizioterapii i kurortologii, 4, 78-82.

[12] Gil', A. Yu., Milova, E. A., Khalturina, D. A.; Anisimova, V. N. (Ed.) (2015). Profilaktika stareniya dlya vsekh. Moscow: Iz-vo «Uchitel'», 120.

[13] Klatz, R., Goldman, R. (1996). The official antiaging revolution. Basic Health Publications, 637.

[14] Ponomarenko, G. N. (2009). Innovatsionnye tekhnologii fizioterapii. Voprosy kurortologii, fizioterapii i lechebnoy fizicheskoy kul'tury, 4, 3-8.

[15] Ulashhik, V. S. (2013). Fizioterapiya. Noveyshie metody i tekhnologii. Minsk: Knizhnyy Dom, 448.

[16] Maksimov, A. V. (2012). Fizioterapiya: dostizheniya i perspektivy. MEDCOM. Available at: http://www.medcom.spb.ru/publ/info/174

[17] Ponomarenko, G. N. (2002). Fizicheskie metody lecheniya. Saint Petersburg, 586.

[18] Ulashhik, V. S. (2008). Fizioterapiya. Universal'naya meditsinskaya entsiklopediya. Minsk: Knizhnyy Dom, 468.

[19] Shuvalova, I. N. (2015). Vosstanovlenie adaptatsionnykh vozmozhnostey organizma studentov $\mathrm{s}$ ispol'zovaniem zdorov'esokhranyayushhikh apparatov «TopRelax» i «NovuEye». Vestnik sovremennoy nauki, 8, 141-146.

[20] Shuvalova, I. N., Kostin, N. F. (2018). Sanogeneticheskie aspekty ozdorovleniya patsientov vertebro- nevrologicheskogo profilya s ispol'zovaniem massazhno- teplovogo oborudovaniya domashnego primeneniya. Vestnik Fizioterapii i kurortologii, 1, 76-79.

[21] Shuvalova, I. N. (2017). Obosnovanie primeneniya apparata «BodyHealth» v ozdorovitel'noy terapii bol'nykh obliteriruyushhim aterosklerozom sosudov nizhnikh konechnostey. Vestnik fizioterapii i kurortologii, 4, 132-134.

[22] Shuvalova, I. N., Kostin, N. F., Golovan, V. A. (2017). Geroprotektornyy effekt apparatov «NovuMedical». 1 mezhdunarodnaya nauchno-prakticheskaya konferentsiya, po sokhraneniyu tvorcheskogo naslediya i razvitiyu idey A. L. Chizhevskogo. Kaluga, 114-117. 